\title{
How classroom design impacts for student learning comfort: Architect perspective on designing classrooms
}

\author{
Kurnia Widiastuti ${ }^{1}$, Mohamad Joko Susilo ${ }^{2}$, Hanifah Sausan Nurfinaputri ${ }^{3}$ \\ ${ }^{1,3}$ Department of Architecture and Planning, Universitas Gajah Mada, Indonesia \\ ${ }^{2}$ Master of Islamic Studies Department, Universitas Islam Indonesia, Indonesia
}

\section{Corresponding Author:}

Kurnia Widiastuti, Department of Architecture and Planning, Engineering Faculty, Universitas Gajah Mada, 02 Grafika Road, Senolowo, Sinduadi, Mlati, Sleman, Yogyakarta, 55281, Indonesia. Email: k.widiastuti@ugm.ac.id

\begin{tabular}{l} 
Article Info \\
\hline Article history: \\
Received Mar 8, 202 \\
Revised Jun 16, 2020 \\
Accepted Jul 21, 2 \\
\hline Keywords: \\
Classroom design \\
Comfort \\
Formal school \\
Learning \\
Student
\end{tabular}

\begin{tabular}{l} 
Article Info \\
\hline Article history: \\
Received Mar 8, 2020 \\
Revised Jun 16, 2020 \\
Accepted Jul 21, 2020 \\
\hline
\end{tabular}

\begin{abstract}
This study aimed to determine the factors that influence student learning comfort in the classroom and its distribution. This explorative study employed 772 students who were elementary school, junior high school, and senior high school students in several Muhammadiyah Yogyakarta schools. Data collection techniques using open questionnaires. The data analysis technique uses qualitative analysis which consists of three stages: open coding, axial coding, and selective coding. The results showed that the factors that influence learning comfort of students in the classroom include: air circulation, quietness, cleanliness, adequate \& supportive facilities, and peer attendance. These five factors are among other factors that are grouped into two: 1) factors originating from the physical environment (of building \& site themes and of indoor space themes); and 2) factors from within its occupants (of human themes). The theme that shows the highest influence comes from the physical conditions in the classroom, that is indoor space themes.
\end{abstract}

This is an open access article under the CC BY-SA license.

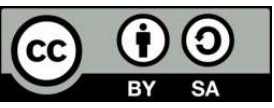

\section{INTRODUCTION}

Nowadays, the policy of schools in Indonesia, both public and private schools, on average implements a full-day school system. This policy was initiated by Minister of Education and Culture in $2016[1,2]$. Previously, this system was only applied to schools in boarding schools. In the full day school system students are at school for approximately 8 hours every day which takes place around 07.00 to 16.00 or at 6.45 to 15.00 according to local time. Compared to the half day system (regular), full day school system means an increase in the duration of learning time from 6-8 to 10-12 hours of learning, where 1 hour of learning is about 35 minutes for the elementary school level. This time includes additional time to rest, pray, and eat. Full day school learning is carried out for 4 days in 1 week. Friday learning takes place in a half day system. Likewise Saturday is generally for extracurricular activities or self-development [3-5].

Because of students spend more time in school, so they do not get bored easily the class should have a fun design, comfortable to learn, and not monotonous [6]. This is because the classroom is the element that most influences student progress and learning success [7, 8]. As happened in public elementary school of 002 Bangkinang Kota, in the classroom carpet was provided with the aim of giving freedom to students to choose where to study, sit on a bench or on a carpet. Even when feeling tired, students are allowed to study while 
lying down [5]. In the elementary school Qur'ani Al-Ikhlash Rappang, Sidenreng Rappang District, provides a place for students to put their student's lunch boxes in the classroom, besides that there are also wall decoration, brooms, and other cleaning tools [9]. Because school facilities are complete, it will cause student satisfaction as the research results by Adedamola, et al. [6], students are satisfied with electricity supply, ceiling finishes, windows/doors and furniture in their classrooms. However, they were not satisfied with the provision of air conditioning and internet facilities in the classroom.

The completeness of school facilities and infrastructure is a supporting factor for the implementation of education [10]. Facilities and infrastructure in the classroom, such as spacious classrooms, air conditioners or fans, LCDs, blackboards or white boards, teacher desks, student desks, teacher chairs, student chairs, chalks, marker, boardmarker, air freshener, etc., play an important role in realizing continuity of learning process. Although not every facility and infrastructure must be available, but the completeness of these learning facilities will create the comfort of learning [11, 12]. Learning comfort is a major factor in achieving success in learning. If learning conditions are comfortable, the learning process will be fun. As a result, student achievement increases [8, 13, 14]. As listed in the Law on the Republic of Indonesia's National Education System Number 20 of 2003 [15], the objectives of education are to create an atmosphere of learning and learning process so that students actively develop their potential.

Generally, the condition of formal school spaces especially in Yogyakarta has so far been normatively arranged. The class facilities that are available are generally teacher's desks, student desks, cupboards, cleaning equipment, blackboards or white boards, and stationery. In other schools, for example in SMP N 15 Yogyakarta has classes that are equipped with CCTVs, speakers, presence boards, LCDs, and cupboards to store student's mobile phones [16]. Classroom lighting uses sunlight through the window, in addition to other sources from lamps and electrical energy. The arrangement of the desk chair usually faces in one direction on the blackboard with the teacher's desk chairs in front. Cupboards are located in the corner near the teacher's desk. Class conditions that seem rigid and uncomfortable can be found every day in classes that has not been neatly organized. This situation is impressed that implementation of learning in formal schools is still limited to normative, so that makes students feel more tired and bored quickly, not comfortable in following the lessons. Especially if there is an indication of students, who often see the wall clock, as if the class is like a "cell" for him. Although in certain schools that have excelled also have far better space planning. According to Amirin, et al. [17], schools in the Yogyakarta city vary in design of their classrooms, there are ideal schools that meet standard size of $9 \mathrm{~m} \times 8 \mathrm{~m}$ uniformly throughout the classrooms and there are also various sizes. In addition, there is also a classroom design that is too large $(10 \mathrm{~m} \mathrm{x} 8 \mathrm{~m})$, so it is too broad if it is used as a standard class with class size of 34 students.

The fact that occurred in Yogyakarta schools, especially in Pakualaman District according to the results of a study by Ambarsari [18] showed that $41 \%$ of students felt the classroom conditions were comfortable for learning, while $36 \%$ of students felt the class was not comfortable for learning. Factors that cause students to be uncomfortable learning in class include: safety of classroom buildings including poor floor, wall, and ceiling conditions; availability and condition of chairs, desks in class, lack of vegetation around classrooms; and noise outside the classroom. Discomfort that occurs in SMA Negeri 8 Yogyakarta, as described by Khatimah [19], is caused by an internet connection that is still difficult to reach and textbooks are lacking. School conditions as described above includes the other side which is not fulfilled in criteria of comfort in student learning space. According to Widodo [20], student learning comfort can be realized with clean classrooms, good classroom lighting, comfortable room temperature (around $25^{\circ}-28^{\circ} \mathrm{C}$ ), seating arrangement and ergonomics, use of instrumental music, low class noise levels, discipline classrooms, and structuring learning communities (student-teacher-parents) that support the learning process. Although the comfortable temperature categories in each region differ, for example in the Mandau region, schools that meet optimal comfortable conditions with temperatures ranging from $25.90{ }^{\circ} \mathrm{C}$ to $27.60{ }^{\circ} \mathrm{C}$ [11]. Meanwhile, in classrooms during the summer in Taiyuan, China, students prefer cooler temperatures than neutral environments which are around $21.85{ }^{\circ} \mathrm{C}$ [21]. In the Brazilian city of São Luis (hot and humid climate) with temperatures between $23-24{ }^{\circ} \mathrm{C}$ is considered the most comfortable [12].

The thermal comfort of classrooms is an important issue for realizing the comfort of study rooms [21]. There are at least 4 categories of elements forming a comfortable study room [22]: 1) elements forming the space, including: color selection of wall paint, carpet, ceiling; 2) aesthetic element of space, for example putting up photos of president and vice president and national symbol, putting up the work of student, photographs of student's activities, pictures/posters that support the theme of learning, school rules, quotes, and verses Holly Qur'an; 3) furniture material elements, for example pieces of chairs and their appropriate size, shape of tables, paint tables and chairs; and 4) arrangement of furniture that supports interpersonal communication. Scientific studies reveal the importance of classroom symbolic features, such as objects and wall decorations in influencing student learning and achievement in the environment. This symbol as a form of information about their existence as valued students and included in the class [8].

Int. J. Eval. \& Res. Educ. Vol. 9, No. 3, September 2020: 469 - 477 
Previous research on classrooms that proved to be most influential on student achievement was carried out by Barrett, et al. [7]. Three aspects of learning environment are emphasized as conceptual models in this study, include: naturalness, individualization, and stimulation (SIN). The method used is the EB (Environment-behavior) model. The results of the study found seven key classroom design parameters that influence student learning comfort including: light, temperature, air quality, ownership, flexibility, complexity, and color. Next, a study conducted by Kahya [23], showed that there was a mismatch between dimensions of classroom furniture and students' anthropometric measures in terms of: chair height, chair depth, and table height which had an impact on discomfort in classroom learning. Kumar, et al. [24] also examined the effect of thermal comfort on students. The results showed that students preferred the high airspeed range to restore comfort, either by opening windows and doors or by turning on ceiling fans. $80 \%$ use of ceiling fans at indoor air temperatures of $29{ }^{\circ} \mathrm{C}$. In addition, scientific studies conducted by Cheryan, et al. [8], say that the structural facilities of buildings greatly influence learning. Inadequate lighting, noise, low air quality, and poor heating in the classroom are significantly associated with worse student performance.

Therefore, to be able to know the comfort of learning spaces especially Muhammadiyah schools in Yogyakarta, it is necessary to identify the study space criteria that support creation of learning comfort. This study aims to determine the factors that influence student learning comfort in the classroom and its distribution. This research is similar to existing studies that are exploratory research. The difference between this research and existing research lies in the object of research and the questionnaire used does not limit choices to physical aspects. The education level of the object of this study is broader than Berret's research, which includes elementary, junior high school, and senior high school levels, but the scale of the sample in this study is smaller. In the end, the results of this study are expected to be a consideration in designing a comfortable school or any place of learning that can positively influence student achievement.

\section{RESEARCH METHOD}

This research was an exploratory research. The research methods used qualitative as well as quantitative methods [25] with explorative research categories [26]. The data collection uses surveys in form of an open-ended question. The questionnaire was distributed directly to 772 respondents, who were 245 elementary school students, 265 junior high school students, and 262 senior high school students from the Muhammadiyah foundation school in Yogyakarta. The data analysis uses qualitative content analysis which consists of three stages: open coding, axial coding, and selective coding [27]. In the open coding stage, respondents' answers which are text data are identified to obtain keywords. Axial coding stage is to make a category of keywords that have been obtained at the open coding stage. Finally, the selective coding stage is based on the relationship between categories.

The initial stage of content analysis is open coding or identification of keywords from respondents' answers. At this stage, 1139 subdata from 772 samples were produced. After open coding, grouping of keywords (axial coding) has been obtained to become a category. This category is then used for the next stage of analysis, distribution analysis.

\section{RESULTS AND DISCUSSION}

Based on the results of the study, 18 categories of student's opinions regarding the comfort of the room in their class: building strength \& durability; connection with nature; proportion of indoor space and occupants; quietness in building \& site themes; air circulation on the theme of buildings \& site; cleanliness; visual quality; space planning; study atmosphere; lighting; air circulation in the theme of indoor space; adequate \& supportive facilities; supervisor presence; peer attendance; student behavior; quietness in human themes; motivation; and class impression. All of these categories can be explained in Table 1.

Based on the data in Table 1, a percentage diagram for each category can be made as in Figure 1. Based on Figure 1, it can be seen that air circulation factor shows the highest percentage and is very dominant among all categories (31.12\%); followed by a quietness factor $(14.10 \%)$; cleanliness $(12.19 \%)$; adequate \& supportive facilities $(10.10 \%)$; and peer attendance $(7.46 \%)$. This tendency is different when compared with the results of research Barrett, et al. [7] which shows that lighting is the most determining factor in optimizing space in learning.

The categories then grouped by levels of control into three (3) major themes: Building \& Site, Indoor space, and Humans. Most categories can be fully classified under these themes, but some categories are divided into several themes at once. These three themes can also be simply classified as physical (building \& site and indoor space) and non-physical (human) factors. The proportion of themes and the details of each theme can be seen in Figure 2.

How classroom design impacts for student learning comfort: Architect perspective on ... (Kurnia Widiastuti) 
Table 1. Grouping data on respondent's answers based on categories and themes

\begin{tabular}{|c|c|c|c|c|c|}
\hline \multicolumn{2}{|c|}{ Building \& Site } & \multicolumn{2}{|c|}{ Indoor space } & \multicolumn{2}{|r|}{ Human } \\
\hline $\begin{array}{l}\text { Building } \\
\text { Strength \& } \\
\text { Durability }\end{array}$ & $\begin{array}{l}\text { Strong school buildings, } \\
\text { Floor tiles are broken, } \\
\text { Ancient floor, Leak roof, } \\
\text { To take shelter }\end{array}$ & Cleanliness & $\begin{array}{l}\text { Clean, Dirty wall, } \\
\text { Trash, Cleaning } \\
\text { service, Picket, air } \\
\text { quality }\end{array}$ & $\begin{array}{l}\text { Supervisor } \\
\text { presence }\end{array}$ & $\begin{array}{l}\text { Teacher, Ask the teacher, } \\
\text { Guidance is easy to follow, } \\
\text { Teacher is not fierce }\end{array}$ \\
\hline $\begin{array}{l}\text { Connection } \\
\text { with Nature }\end{array}$ & $\begin{array}{l}\text { View from the window, } \\
\text { There is a garden, Near } \\
\text { the park }\end{array}$ & $\begin{array}{l}\text { Visual } \\
\text { Quality }\end{array}$ & $\begin{array}{l}\text { Decoration, Beautiful, } \\
\text { Neat, Manicured, Wall } \\
\text { color }\end{array}$ & $\begin{array}{l}\text { Peer } \\
\text { attendance }\end{array}$ & $\begin{array}{l}\text { Friends, working together, } \\
\text { learning together, joking, } \\
\text { discussion friends, fun } \\
\text { friends }\end{array}$ \\
\hline $\begin{array}{l}\text { Proportion } \\
\text { of Indoor } \\
\text { space and } \\
\text { Occupants }\end{array}$ & $\begin{array}{l}\text { Spacious, large, tight, } \\
\text { Too many people, few } \\
\text { students }\end{array}$ & $\begin{array}{l}\text { Space } \\
\text { planning }\end{array}$ & $\begin{array}{l}\text { Neat furniture, Good } \\
\text { layout }\end{array}$ & $\begin{array}{l}\text { Student } \\
\text { behavior }\end{array}$ & $\begin{array}{l}\text { Cheating, mocking, playing, } \\
\text { studying, students are } \\
\text { difficult to regulate, other } \\
\text { class students enter }\end{array}$ \\
\hline Quietness & $\begin{array}{l}\text { Class on the } 2^{\text {nd }} \text { floor, } \\
\text { undisturbed by other } \\
\text { classes, The next class is } \\
\text { noisy, Close to the road, } \\
\text { Noisy, quiet, There is no } \\
\text { interference from outside }\end{array}$ & Conductivity & $\begin{array}{l}\text { Can study, Suitable for } \\
\text { learning, Good Focus, } \\
\text { Quiet }\end{array}$ & Quietness & $\begin{array}{l}\text { There is a disturbance, } \\
\text { many conquered, noisy } \\
\text { friends, quiet if all are silent }\end{array}$ \\
\hline $\begin{array}{l}\text { Air } \\
\text { circulation }\end{array}$ & $\begin{array}{l}\text { Cold, cool, stuffy, } \\
\text { comfortable, ventilated }\end{array}$ & $\begin{array}{l}\text { Lighting } \\
\text { Air } \\
\text { circulation } \\
\text { Adequate \& } \\
\text { Supportive } \\
\text { Facilities }\end{array}$ & $\begin{array}{l}\text { Curtains, lights, glare } \\
\text { AC, fan } \\
\text { Electricity, clock, } \\
\text { calendar, LCD, WiFi }\end{array}$ & $\begin{array}{l}\text { Motivation } \\
\text { Class } \\
\text { Impression }\end{array}$ & $\begin{array}{l}\text { Get knowledge } \\
\text { Safe, fun, boring, } \\
\text { accustomed }\end{array}$ \\
\hline
\end{tabular}

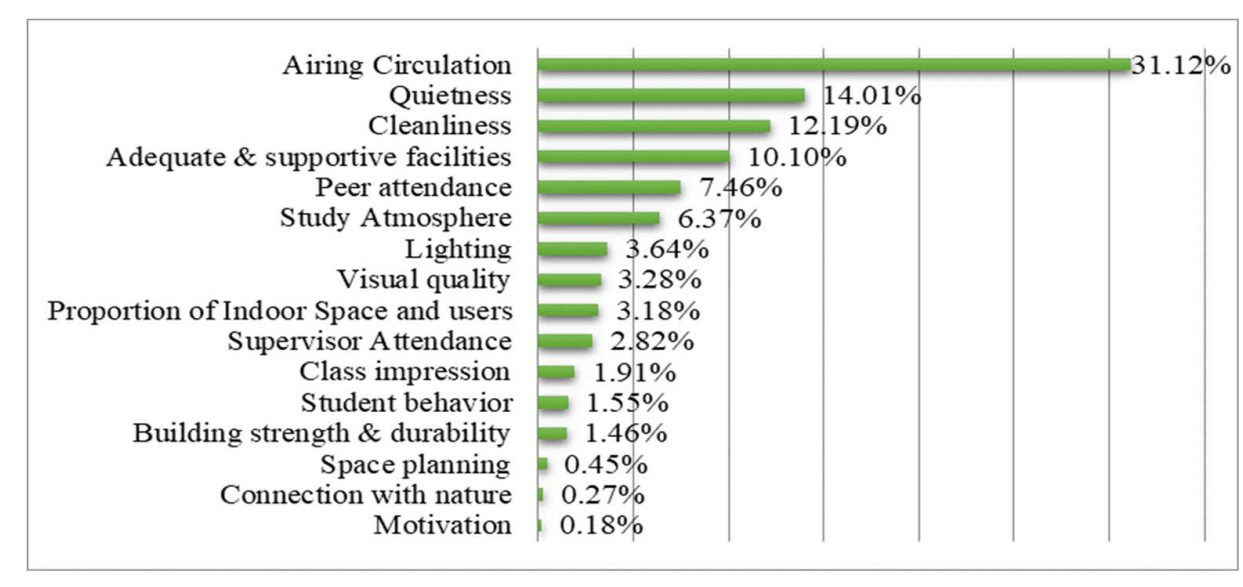

Figure 1. Categories of students' opinions on the comfort of classrooms

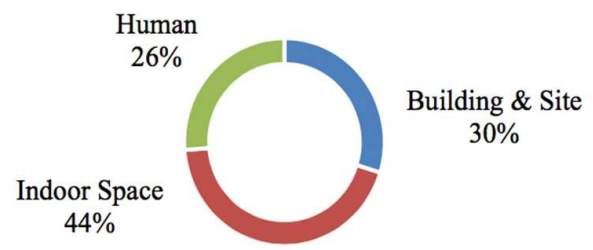

Figure 2. The classification of student's opinion categories becomes theme

\subsection{Building \& site}

In the building \& site theme (30\%), the factors including parts can be controlled or regulated in terms of the physical design stages of building and its properties tend to be fixed. The categories included: building strength \& durability; quietness; lighting; air circulation; proportion of indoor space and occupants. In Table 2 keywords can be detailed in each category. From Table 2, a diagram can be made as shown in Figure 3.

Int. J. Eval. \& Res. Educ. Vol. 9, No. 3, September 2020: 469 - 477 
Table 2. Categories and keywords on building \& site themes

\begin{tabular}{ll}
\hline \multicolumn{1}{c}{ Category } & \multicolumn{1}{c}{ Keywords } \\
\hline Connection with nature & View from the window, there is a garden, near the park \\
Building Strength \& Durability & $\begin{array}{l}\text { Strong school buildings, broken floor, leak roof, take shelter from the rain } \\
\text { Quietness }\end{array}$ \\
$\begin{array}{l}\text { Quiet, noisy, class on the } 2^{\text {nd }} \text { floor, not disturbed by other classes, close to the road, } \\
\text { interference from outside }\end{array}$ \\
Lighting & Bright, dark, enough lighting, sunlight coming in window \\
Air circulation & Cold, cool, hot, fetid, stuffy, comfortable, ventilation, window \\
Proportion of indoor space & Spacious, large, small, tightness, too many people, little students, broad fitting \\
and occupants & compared to the number of students \\
\hline
\end{tabular}

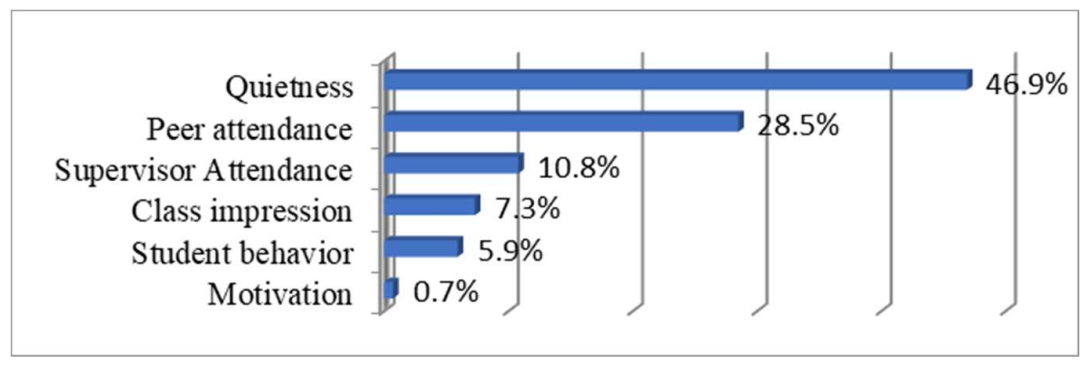

Figure 3. The percentage of factors that influence on building \& site themes

In building \& site themes, the air circulation category was the most dominant factor $(69.0 \%)$. This category is largely determined by keywords such as: windows, ventilation, heat, and cool. Air circulation is related to the amount of air/wind that entering the room. Basically, the window functions for air circulation, however too large a window size can also cause over heating. Actually, a practical way to obtain thermal comfort is to use AC in the room [12]. However, the use of AC can increase the use of electrical energy. Scientific studies find other ways that are most inexpensive through architectural approaches, by designing buildings that consider orientation to the sun and wind direction, the use of architectural elements and building materials, and the use of landscape elements, for example by the doble layer facade technique [28].

The category proportion of indoor space and occupants $(10.7 \%)$ is related to the freedom of movement every student in the classroom. The flexibility of student's space (kinesphere) allows students to move. Especially in early childhood requires more space to move, because they are relatively active and more difficult to focus in a long duration [29]. Specially arranged space can help increase children's intelligence [30]. The government has set standard area of classroom contained in the Minister of National Education Regulation of Republic Indonesia Number 24 [31] set at $2 \mathrm{~m}^{2} / \mathrm{students}$ with a minimum area of $30 \mathrm{~m}^{2}$ for study groups with students less than 15 people, and a minimum width of $5 \mathrm{~m}$ classrooms.

The lighting category occupies the third position with a percentage of $8.6 \%$. Some students respond positively to their classroom condition which gets access to natural lighting in the appropriate intensity. However, orientation of the building and the "tritisan" (other forms of external shade) need to be considered to avoid direct sunlight or glare. Government standards regarding lighting [31] set that in classrooms must have facilities that allow adequate lighting to read books and to provide views outside the room, because poor lighting can reduce student achievement [8].

The quietness category gets a percentage of $5.8 \%$. The building has a big role in creating a calm atmosphere. Some students complained of noise from the highway around their school. School buildings, especially in urban areas must pay attention to class distance from main traffic and adjacent busy areas. Regarding noise from inside the school, distance or class boundary material needs to be considered so that the activities of students in each class do not interfere with each other.

Building strength \& durability (4.90\%) is not a dominant factor according to students, although it is actually crucial. The keywords that appear in this category tend to be small parts of the building which usually have a relatively short lifespan such as roofs and floors. Furthermore, the connection with nature category $(0.99 \%)$ was less dominant in creating calm learning in the classroom, although in the research of Barret, et al. [7] connection with nature is proven as a supporting factor for weak learning success. Indirectly the natural view from this window gives its effect when the position of the window sill is below the eye level in students.

How classroom design impacts for student learning comfort: Architect perspective on ... (Kurnia Widiastuti) 


\subsection{Indoor space}

In the indoor space theme (44\%), the factors in it can be controlled or regulated in the classroom structuring phase. Although the nature of this theme tends to be temporary, it is the most dominant consideration among other themes. The categories included in the indoor space theme are: adequate and supportive facilities, cleanliness, study atmosphere, visual quality, interior management, lighting, and air circulation. In Table 3, the key words in each category are presented. From Table 3, the diagram can be arranged as in Figure 4.

Table 3. Categories and keywords on the indoor space theme

\begin{tabular}{ll}
\hline \multicolumn{1}{c}{ Category } & \multicolumn{1}{c}{ Keywords } \\
\hline Adequate \& Supporting Facilities & Complete, adequate facilities, learning tool, electric current, hour, calendar, LCD, Wifi, furniture \\
Cleanliness & Clean, dirty, rubbish, cleaning service, students' cleaning rotation, air quality, smells, smells \\
& good \\
Study Atmosphere & Can study, suitable for learning, good, focus, conducive, quiet \\
Visual Quality & Decoration, beautiful, neat, manicured, wall color \\
Space planning & Tidy furniture, good interior layout \\
Lighting & Curtains, lamp, glare \\
Air circulation & AC, fan \\
\hline
\end{tabular}

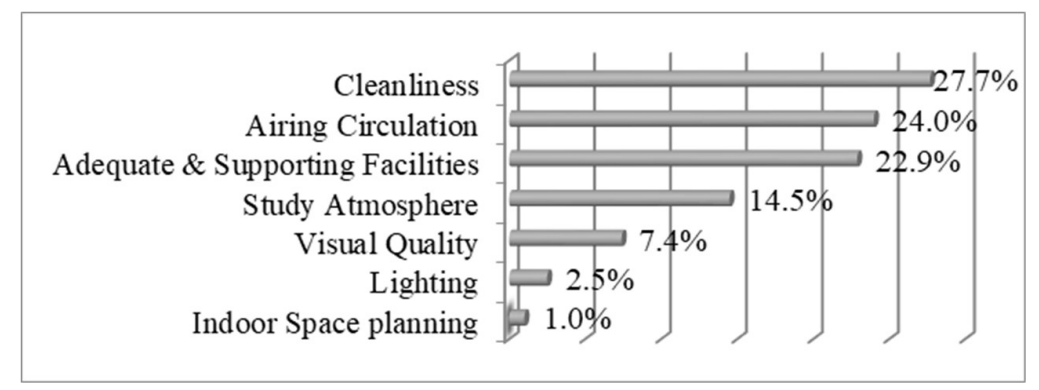

Figure 4. The percentage of factors that influence on indoor space theme

Cleanliness is the most dominant factor in this theme $(27.7 \%)$. The evaluation of cleanliness category is still limited to whether something is seen by the eye. Unlike the case with the category of visual quality, cleanliness related to hygiene, the presence or absence of dirt, and air quality associated with aroma. This fact was not discussed in Berret's research. Dirty or unhealthy environments can have a direct negative influence on the presence and academic performance of students, because intensity is more often exposed to the source of disease [32]. Dirty environment is also associated with a lack of school awareness, especially the role of teacher in contributing to students towards hygiene and environmental care attitudes [33]. While a clean environment causes school members to be comfortable in school and learning feels more fun [34].

Cleanliness, high and low visual quality (7.4\%), and space planning (1\%) not only have an impact on physical health, but can also affect the occupant's mental state and behavior. Every member of the school community needs clean air to breathe, clean water to drink, a safe place for activity, and protection from extreme temperatures and ultraviolet radiation [32]. Through the movement to create a sense of belonging to the class, it can help improve student's concern for the classroom environment and create a sense of responsibility by making the class feel special [7]. Some respondents expressed a positive impression on their class which had ornaments, wall magazines, and unusual wall paint colors. The results of learning displayed on the classroom wall can also encourage student participation and involvement in learning process [8].

Berret's research [7] shows that students get better academic achievement in rooms where the temperature is more easily controlled. The superior quality and quantity of electrical lighting, central heating with thermostatic control, and mechanical ventilation can provide an opportunity for teachers/students to adjust the environment to a more comfortable level. In this research, in the air circulation category in the room, it is often mentioned about additional ventilation devices such as air conditioners and fans. The presence of air conditioners or fans also helps overcome the problem of unpleasant odors in the cleanliness category. The use of air conditioners as air conditioning strategies in various climates is a common thing to do [12]. In the lighting category a lot is mentioned about the number of lamps and their quality is adequate or not. In addition, the presence of curtains is also mentioned by respondents. It has a role as a tool for lighting control from the outside to inhibit the intensity of incoming sunlight.

Int. J. Eval. \& Res. Educ. Vol. 9, No. 3, September 2020: 469 - 477 
The category of facilities that are adequate and support the learning process gets a percentage of $22.9 \%$ in influencing student comfort. The facilities mentioned by respondents include: the projector and screen, internet network (WiFi), clock, calendar, and comfortable student desk and chair conditions and in good condition (not dirty, perforated, or damaged). Berret's research [7], shows that furniture that is ergonomic and comfortable for students greatly influences the learning process. Some students also complained about the electricity that is sometimes interrupted. According to Cheryan et al. [8], building structural facilities greatly influence learning. More than half of U.S. schools having inadequate structural facilities are significantly associated with poorer student performance. Therefore, it is important to design and determine features of class design that can improve student achievement.

\subsection{Human}

In human themes $(26 \%)$, the categories included are directly influenced by their occupants. These categories include: peer attendance, supervisor presence, quietness, motivation, student behavior, and class impression. In Table 4 can be seen keywords in each category. Based on Table 4, the diagram can be arranged as in Figure 5.

Table 4. Categories and keywords on human themes

\begin{tabular}{ll}
\hline \multicolumn{1}{c}{ Category } & \multicolumn{1}{c}{ Keywords } \\
\hline Peer attendance & Friend, work together, studying together, kidding, discussion friend, fun friend \\
Supervisor presence & Teacher, ask the teacher, guidance is easy to follow, teacher is not fierce \\
Quietness & There is interference, many are noisy, noisy friend, it's quiet if everyone is silent \\
Motivation & Get knowledge \\
Student behavior & Cheat, mock, played, study, students are difficult to manage \\
Class impression & Secure, it's fun, boring, accustomed \\
\hline
\end{tabular}

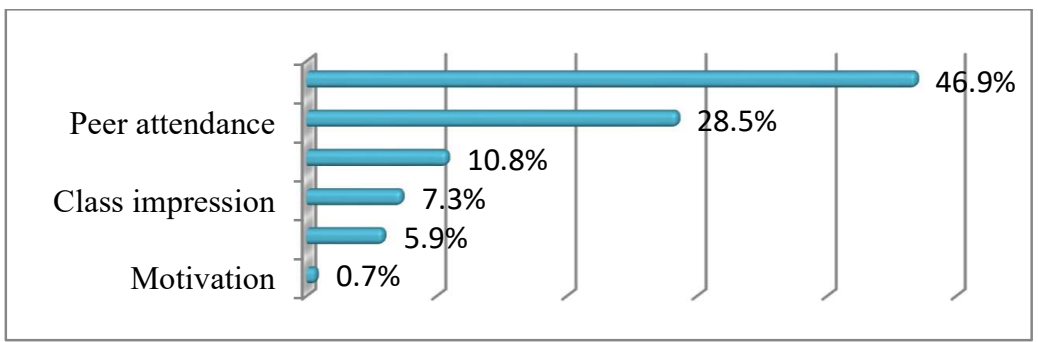

Figure 5. The percentage of factors that influence human themes

From the explanation of indoor space theme, it can be understood that some of the attitudes or activities of humans in it are the impact of the conditions and the arrangement of physical space. In the human theme, the category of quietness dominated this theme with a percentage of $46.9 \%$. Many respondents submit complaints in the form of "noisy friends" or some in positive sentences "class is quiet when everyone is silent". This sentence does not mean that the activities or attitudes of occupants are the main cause of the problem of quietness, the character of students who are indeed inclined to be active and crowded, or teacher is not able to manage students can be other factor causing the problem. In category of student behavior $(5.9 \%)$, some respondents showed submissive attitude to the function of room by writing "class (is a) place to learn", while some mentioned negative student behavior such as cheating, teasing, difficult to manage, and tend to play in the classroom. These behaviors can come from students themselves, as well as the impact of physical environment.

The category of peer attendance gained a percentage of $28.5 \%$. Some students feel comfortable with their class, because there are their friends in it. Not only caused by the character of students themselves, activities that can be done together provide motivation in learning, such as work, study, and discuss. Studying together with peers forms a sense of togetherness and support. Peers also provide the highest role in forming the character of student's environmental care attitudes compared to the role of the school and family environment [33]. Besides peer attendance, supervisor presence $(10.8 \%)$ or teacher is also the reason some students feel comfortable with their class. Feelings of being accompanied, opportunities to ask the teacher, tutoring that is easy to follow, and teacher is not fierce are some of keywords in this category. The role of teacher in digital era is more like a motivator and facilitator [35]. The existence of teacher interaction with students is intended to achieve maximum learning outcomes [36, 37].

How classroom design impacts for student learning comfort: Architect perspective on ... (Kurnia Widiastuti) 
Based on these descriptions, long before designing school buildings, it is important to understand factors that influence student learning comfort. A comfortable and conducive classroom environment is the dream of every student. The learning comfort will be found when the learning environment is supportive. The results of this study found that the factors that influence student learning comfort include: air circulation factors, quietness, cleanliness, adequate \& supportive facilities, and peer attendance. These factors are then grouped into two: 1) factors originating from the physical environment (building \& site themes and indoor space themes); and 2) factors from within its occupants (human themes). The factor that shows the highest influence is the factor that comes from the physical conditions in the classroom (indoor space themes).

Categories which make up each theme (from 3 big themes) interrelated with each other and can be controlled from various levels. Aspiration and lighting factors can be controlled at the building design stage, for example with natural double layer facade techniques for efficient energy consumption [28, 38, 39] and supported by space planning in class. The quietness factor is influenced by the classroom environment which can be controlled by the physical design of school and also by its occupants. Furthermore, the quietness and students' behavior on human themes are also influenced by the quality of physical conditions, including: the proportion of indoor space and occupants, space planning, cleanliness, and visual quality.

Efforts to create comfortable learning continue to be improved. Various innovations and creativity are carried out, for example through playing instrumental music [40]; prepare certain types of classrooms and provide space for students to move freely (kinesphere) [38]; decorate classrooms, paintings, student work, schedules and school rules, state attributes, and sacred verses that can motivate students [22], provide adequate air circulation and lighting [7], provide natural ventilation through windows and doors classrooms or by using fans or air conditioners $[12,24]$, as well as using lights and utilizing sunlight as lighting. It is important to note that each level of education has a different learning comfort $[39,41]$.

\section{CONCLUSION}

The comfort of students in the classroom is mostly influenced by several factors including: air circulation, quietness, cleanliness, adequate \& supportive facilities, and peer attendance. These five factors are among other factors that are grouped into two: 1) factors originating from the physical environment (of building \& site themes and of indoor space themes); and 2) factors from within its occupants (of human themes). The theme that shows the highest influence comes from the physical conditions in the classroom, that is indoor space themes.

\section{ACKNOWLEDGEMENTS}

Authors would like to thank you very much to: Faculty Research Supervisory Board (BPPF), Faculty of Engineering, Gadjah Mada University, Yogyakarta. Also, to Muhammadiyah Regional Head of Yogyakarta City, Chairperson of the PDM Dikdasmen Assembly Yogyakarta City, and all school principals are used as observation and research sites.

\section{REFERENCES}

[1] Marwati, "Full day school idea according to experts," Gajah Mada University, 2016.

[2] I. Nurkholis, Masrukhi, and Juhadi, "Full-day school application and its effect on character building of students (case study at elementary school nasima semarang)," J. Educ. Soc. Stud., vol. 7, no. 2, pp. 224-230, 2018.

[3] A. Aziz, H. Setiawan, and S. Mahendra W.A., "The impact of implementing full school in Indonesia," in Proceedings of National Seminar in Education 2017, pp. 248-260, April 2017.

[4] I. Iftayani and Nurhidayati, "Self concept, self esteem and school system: The study of comparation between fullday school and halfday school in purworejo," Guid. J. Gudance Couns., vol. 6, no. 1, pp. 53-60, 2016.

[5] N. Librianty, "Full day school education management in 002 Bangkinang, Kampar Regency City," J. Basicedu, vol. 2, no. 1, pp. 69-76, 2018.

[6] O. Adedamola, D. Daniel, and A. Ayudele, "Comparative analysis of students' satisfaction with classroom facilities in nigerian private universities," J. Stud. Educ., vol. 5, no. 4, pp. 242-257, 2015.

[7] P. Barrett, F. Davies, Y. Zhang, and L. Barrett, "The impact of classroom design on pupils' learning: Final results of aholistic, multi-level analysis," Build. Environ., vol. 89, no. July, pp. 118-133, 2015.

[8] S. Cheryan, S. A. Ziegler, V. C. Plaut, and A. N. Meltzoff, "Designing classrooms to maximize student achievement," Behav. Brain Sci., vol. 1, no. 1, pp. 4-12, 2014.

[9] Jumiati and Lababa, "The implementation of reinforcement education character at elementary school qur'ani alikhlash rappang sidenreng sappang regency," J. Ris. Pendidik. Dasar, vol. 02, no. 2, pp. 81-88, 2019.

[10] M. Novita, "Good facilities and infrastructure become the spearhead of the success of Islamic educational institutions,” NUR EL-ISLAM J. Pendidik. dan Sos. Keagamaan, vol. 4, no. 2, pp. 97-129, 2017.

Int. J. Eval. \& Res. Educ. Vol. 9, No. 3, September 2020: 469 - 477 
[11] Gunawan and F. Ananda, "The thermal comfort aspect of the study room of a public high school building in the District of Saber," J. Inovtekpolbeng, vol. 7, no. 2, pp. 98-103, 2017.

[12] C. Buonocore, R. De Vecchi, V. Scalco, and R. Lamberts, "Thermal preference and comfort assessment in airconditioned and naturally-ventilated university classrooms under hot and humid conditions in Brazil," Energy Build., vol. 211, p. 109783, Mar 2020.

[13] D. Lucardie, "The impact of fun and enjoyment on adult's learning," Procedia - Soc. Behav. Sci., vol. 142, pp. 439-446, 2014.

[14] M. Bustari, "Optimizing classroom rehabilitation in supporting the implementation of 9-year compulsory education," J. Manaj. Pendidik., vol. 12, no. 2, pp. 76-90, 2016.

[15] Law on the Republic of Indonesia's national education system number 20, Law on the Republic of Indonesia's national education system, number 20, 2003.

[16] W. Laksono, "Report of guided field practice activities (PLT): Location of junior high school 15 Yogyakarta," 2017.

[17] T. M. Amirin, W. Wijayanti, and C. S. A. Jabar, "Human and materials resources conditions of the 'less favorite' public secondary schools in Yogyakarta," J. Penelit. Ilmu Pendidik., vol. 9, no. 1, pp. 1-11, 2016.

[18] L. Ambarsari, "The convenience of student learning in grades IV SD Negeri throughout the Pakualaman subdistrict in the 2014/2015 school year," 2015.

[19] H. Khatimah, "A description of school well-being among students in the acceleration class program in SMA Negeri 8 Yogyakarta," Psikopedagogia, vol. 4, no. 1, pp. 20-30, 2015.

[20] W. Widodo, "Realizing the convenience of student learning, enjoyable learning, and meaningful learning in elementary school," Ar-Risalah, vol. XVIII, no. 2, pp. 22-37, 2016.

[21] S. Jing, Y. Lei, H. Wang, C. Song, and X. Yan, "Thermal comfort and energy-saving potential in university classrooms during the heating season," Energy Build., vol. 202, p. 109390, Nov 2019.

[22] N. Prasetya, "Study of the interior aspects of the study and play spaces in kindergartens in Surakarta," Dimens. Inter., vol. 10, no. 1, pp. 23-32, 2012.

[23] E. Kahya, "Mismatch between classroom furniture and anthropometric measures of university students," Int. J. Ind. Ergon., vol. 74, p. 102864, Nov 2019.

[24] S. Kumar, M. K. Singh, A. Mathur, J. Mathur, and S. Mathur, "Evaluation of comfort preferences and insights into behavioural adaptation of students in naturally ventilated classrooms in a tropical country, India," Build. Environ., vol. 143, no. October, pp. 532-547, 2018.

[25] J. W. Creswell, Research Design Qualitative, Quantitative, And Mixed Methods Approaches, 3rd ed. California: SAGE Publication, 2008.

[26] L. Groat and D. Wang, Architectural Research Methods. New York: John Wiley \& Sons Inc, 2002.

[27] J. W. Creswell, Qualitative inquiry and research design: Choosing among five approach, 2nd ed. SAGE Publication, Inc., 1997.

[28] S. S. Napitupulu, "Effect of building orientation and wind speed on the shape and dimensions of the filter on the facade of the apartment building (case study: Marunda flats, cilincing, Jakarta)," E-Journal Grad. Unpar, vol. 1, no. 2, pp. 75-89, 2014.

[29] R. D. Nur'aini, "Space for early childhood in the indoor learning space in the Ratnaningsin Yogyakarta playgroup," in Seminar Nasional Riset Arsitektur dan Perencanaan (SERAP), vol. 3, no. 22-23 August, pp. 85-96, 2014.

[30] H. Mufrizon, "Architecture and space for children in the environment," Ultim. J. Komun. Vis., vol. 9, no. 2, pp. 39-47, 2018.

[31] Regulation of the Minister of National Education of the Republic of Indonesia Number 24, Regulation of the Minister of National Education of the Republic of Indonesia. Jakarta, 2007.

[32] World Health Organization, "The physical school environment: An essential component of a health-promoting school," USA: World Health Organization, 2004.

[33] R. M. Tamara, "The role of the social environment towards the formation of a caring attitude for students in high school in Cianjur district," Gea J. Pendidik. Geogr., vol. 16, no. 1, pp. 44-55, 2016.

[34] N. Hidayati, "Students' perception of environmental cleanliness at SDN 51 Banda Aceh," J. Ilm. Mhs. Prodi PGSD FKIP Unsyiah, vol. 1, no. 1, pp. 78-87, 2016.

[35] S. S. Putri, M. Japar, and R. Bagaskorowati, "Increasing ecoliteracy and student creativity in waste utilization," Int. J. Eval. Res. Educ., vol. 8, no. 2, pp. 255-264, 2019.

[36] N. Mercer, S. Hennessy, and P. Warwick, "Dialogue, thinking together and digital technology in the classroom: Some educational implications of a continuing line of inquiry," Int. J. Educ. Res., vol. 97, pp. 187-199, 2019.

[37] A. Salehi, "Teacher and student interactions and characteristics from critical theorists school," Int. J. Eval. Res. Educ., vol. 8, no. 2, pp. 313-317, 2019.

[38] M. Jowkar, H. B. Rijal, J. Brusey, A. Montazami, S. Carlucci, and T. C. Lansdown, "Comfort temperature and preferred adaptive behaviour in various classroom types in the UK higher learning environments," Energy Build., vol. 211, p. 109814, Mar 2020.

[39] M. K. Singh, R. Ooka, H. B. Rijal, S. Kumar, A. Kumar, and S. Mahapatra, "Progress in thermal comfort studies in classrooms over last 50 years and way forward," Energy Build., vol. 188, pp. 149-174, Apr 2019.

[40] Nuryaman and S. Zulviah, "The influence of instrumental music playback on the comfort of reading readers in the library of the University of Muhammadiyah Sukabumi," Berk. Ilmu Perpust. dan Inf., vol. 15, no. 1, pp. 60-73, 2019.

[41] D. Wang, J. Jiang, Y. Liu, Y. Wang, Y. Xu, and J. Liu, "Student responses to classroom thermal environments in rural primary and secondary schools in winter," Build. Environ., vol. 115, pp. 104-117, Apr 2017.

How classroom design impacts for student learning comfort: Architect perspective on ... (Kurnia Widiastuti) 